\title{
CARA MENANGGULANGI KUALITAS PENDIDIKAN DI INDONESIA MELALUI SUPERVISI PENDIDIKAN BERDASARKAN PENYEBAB NYATA RENDAHNYA KUALITAS PENDIDIKAN
}

\author{
INDAH KOMALA SARI
}

Email : indahkomalasari1999@gmail.com

\begin{abstract}
ABSTRAK
Kualitas pendidikan di Indonesia hingga saat ini belum bisa dikatakan baik. Hal ini dikarenakan masih banyak sekolah yang belum memiliki sarana dan prasarana yang lengkap serta rendahnya kualitas guru dan prestasi siswa. Hal ini tentu menjadi penyebab rendahnya kualitas pendidikan di Indonesia.
\end{abstract}

Kata kunci : supervisi, kualitas dan pendidikan

PENDAHULUAN

Rendahnya kualitas pendidikan merupakan permasalahan yang sampai sekarang masih dihadapi oleh bangsa Indonesia. Hal ini dikarenakan oleh kurangnya kesadaran masyarakat akan pentingnya pendidikan bagi anak bangsa, terlebih lagi kurangnya peran serta pemerintah dalam meningkatkan mutu pendidikan menjadi penghambat kualitas pendidikan di Indonesia. Yang kita rasakan sekarang adalah adanya ketertinggalan didalam mutu pendidikan. Baik pendidikan formal maupun informal. Mutu bangsa bergantung pada pendidikan yang mampu menjunjung nilai-nilai dan memilikfi kemampuan membentuk watak, manusia yang beriman dan mengembangkan potensi dalam dirinya.

Setelah kita amati, nampak jelas bahwa masalah yang serius dalam peningkatan mutu pendidikan di Indonesia adalah rendahnya mutu pendidikan di berbagai jenjang pendidikan, baik pendidikamn formal maupun informal. Dan hal itulah yang menyebabkan rendahnya mutu pendidikan yang menghambat penyediaan sumber daya manusia yang mempunyai keahlian dan keterampilan untuk memenuhi pembangunan bangsa di berbagai bidang.Dengan adanya pendidikan yang mencakup nilai, budaya, dam pengetahuan akan menambah wawasan berpikir yang diberikan melalui pendidikan formal disekolah. Sekolah adalah salah satu instansi yang memiliki tugas dan kewajiban sebagai fasilitator proses belajar agar dapat mencapai keberhasilan potensi pendidikan.

Berdasarkan uraian diatas, permasalahan dalam tulisan ini adalah (1) Bagaimana cara meningkatkan kualitas guru dan prestasi siswa ? Bagaimana cara meningkatkan sarana dan prasarana ? Tujuan tulisan ini adalah (1) Untuk mengetahui cara meningkatkan kualitas guru dan prestasi siswa. (2) Untuk mengetahui cara meningkatkan sarana dan prasarana.

\section{PEMBAHASAN}




\section{Rendahnya Kualitas Guru dan Prestasi Siswa}

Keadaan guru di Indonesia bisa dikatakan amat memprihatinkan. Hal ini dikarenakan kebanyakan guru belum memiliki profesionalisme yang memadai untuk menjalankan tugasnya. Masih banyak guru yang seenaknya dalam menjalankan tugas, seperti : terlambat masuk kelas, lebih banyak bercerita dibanding menjelaskan pelajaran, kurang memahami konsep materi yang akan diajarkan, kurang memahami karakter siswa bahkan masuk ke dalam kelas hanya untuk memberikan tugas lalu pergi meninggalkan kelas. Walaupun guru dan pengajar bukan satusatunya faktor penentu keberhasilan pendidikan tetapi, pengajaran merupakan titik sentral pendidikan dan kualifikasi, sebagai cermin kualitas, tenaga pengajar memberikan andil sangat besar pada kualitas pendidikan yang menjadi tanggung jawabnya. Kualitas guru dan pengajar yang rendah juga dipengaruhi oleh masih rendahnya tingkat kesejahteraan guru.

Gambaran prestasi belajar siswa sebagaimana hasil penilaian yang dilakukan oleh International Association for the Evaluation of Educational Achievement Study Center Boston College tersebut, diikuti oleh 500.000 siswa dari 63 negara terhadap Trends in Mthematics and Science Study (TIMSS); Indonesia diwakili oleh siswa keals VIII tahun 2011. Hasil penilaian tersebut mengungkapkan bahwa Indonesia dalam bidang Matematika berada di urutan ke-38 dengan skor 386 dari 42 negara yang siswanya di tes (skor Indonesia turun 11 angka dari penilaian tahun 2007). Peringkat pertama diraih oleh siswa Korea (613), selanjutnya diikuti Singapura (500). Bidang sains, Indonesia berada di urutan ke-40 dengan skor 406 dari 42 negara (skor Indonesia turun 21 angka dari penilaian tahun 2007).(Sabandi, 2013)

\section{Rendahnya Sarana dan Prasarana}

Untuk sarana dan prasarana, bisa kita amati bahwa masih sangat banyak sekolah yang kekurangan sarana dan prasarana. Seperti halnya, gedung sekolah banyak yang rusak, kepemilikan dan penggunaan media belajar sangat rendah, buku perpustakaan tidak lengkap, laboratorium tidak standard, pemakaian teknologi informasi tidak memadai dan sebagainya. Bahkan masih banyak sekolah yang tidak memiliki gedung sendiri, tidak memiliki perpustakaan , tidak memiliki laboratorium dan sebagainya. Hal tersebut tentu sangat akan mempengaruhi secara langsung kualitas pendidikan. Maka dari itu, sangat penting bagi kita untuk meningkatkan sarana dan prasarana agar pembelajaran bisa berjalan dengan sangat baik sehingga meningkatnya kualitas pendidikan kita.(chotijah, 2015)

\section{PENUTUP}

\section{KESIMPULAN}

Kualitas pendidikan di Indonesia memang masih sangat rendah bila dibandingkan dengan kualitas pendidikan di negara lain. Hal-hal yang menjadi penyebab utama yaitu rendahnya kualitas guru dan prestasi siswa serta sarana dan prasarana yang kurang memadai. Adapun solusi 
yang dapat diberikan dari permasalahan diatas adalah dengan mengubah sistem-sistem social yang berkaitan dengan sistem pendidikan, dan meningkatkan kualitas guru serta prestasi siswa.

\section{SARAN}

Perkembangan dunia di era globalisasi ini banyak menuntut perubahan ke sistem pendidikan nasional yang lebih baik serta mampu bersaing secara sehat dalam segala bidang. Salah satu cara yang harus dilakukan bangsa Indonesia agar tidak semakin ketinggalan yaitu dengan meningkatkan kualitas pendidikannya terlebih dahulu. Dengan meningkatnya kualitas pendidikan, berarti sumber daya yang terlahir akan semakin baik mutunya dan akan tentu mampu membawa bangsa ini bersaing secara sehat dalam segala bidang di dunia Internasional.

\section{REFERENSI}

chotijah, siti. (2015). Masalah Pendidikan di Indonesia. Retrieved from https://sitichotijah269.wordpress.com/tugas-kuliah/tugas-internet-desing/artikel-masalahpendidikan-di-indonesia

Sabandi, A. (2013). Supervisi Pendidikan Untuk Pengembangan Profesionalitas Guru Berkelanjutan. Jurnal Ilmiah Ilmu Pendidikan, XIII(2), 1-9. 